\title{
Estudo da Aderência de Polímero Reforçado com Fibra de Carbono (PRFC) Aplicado pelo Método Near Surface Mounted (NSM)
}

\section{Marina Reis Delgadinho}

\begin{abstract}
This paper intends to evaluate, throughout laboratory tests, the adherence of Carbon Fiber Reinforced Polymer (CFRP) rigid laminates to concrete. In order to evaluate the adherence on the interface concrete/CFRP, Beam Pullout Tests (BPT) will be carried out, based on the procedures described on the document RILEM RC 05 (RILEM, 1982), which was originally designed to evaluate the adherence of steel bars, once there aren't technical recommendations specifically developed to the subject. The laminates will be allocated into grooves on the surface of concrete beams, which will have standardised dimensions and reinforcement. The laminates' adherence length is going to be the variable studied. Therefore, the resistance to adherence between the CFRP, installed using the Near Surface Mounted method, and the concrete element, can be determined.
\end{abstract}

\section{Key words:}

Carbon Fiber Reinforced Polymer, adherence, Near Surface Mounted..

\section{Introduction}

During the last decades, a vast number of buildings have reached their project service life; therefore, technologies related to structural reinforcement have been widely studied, seeking alternatives to traditional reinforcement techniques that offer a better price performance ratio. In this scenario, the CFRP presents benefits in terms of cost, high mechanical performance, easy installation, tensile, corrosion and chemical resistance and electromagnetic permeability (FONSECA, 2007).

CFRP is a composite that comprises a polymeric matrix and high resistance carbon fibers. In order to apply the CFRP laminates to the concrete surface, there are two techniques; the Externally Bonded Reinforcement (EBR) and the Near Surface Mounted (NSM) technique, in which the laminates are placed in grooves, which grants protection to vandalism, chemical attacks and mechanical impacts, leads to better anchorage to adjacent members and better bonding (DE LORENZIS \& TENG, 2007).

Despite the importance of adherence on the interface composite/concrete to the structure load transmission to the reinforcement system, few laboratory tests have been carried out in Brazil. Therefore, this paper intends to evaluate the adherence resistance between the CFRP and concrete element, installed through NSM method, aiming to contribute to the research of this theme in Brazil.

\section{Results and Discussion}

The adherence experimental method will be based on the Technical Committee State of Art Report 234-DUC from RILEM (International Union of Laboratories and Experts in Construction Materials, Systems and Structures), dated 2016 (SENA-CRUZ et al., 2016), which describes the project procedure for composite use in concrete structures reinforcement. In order to characterize the interface bonding behavior, beam pullout tests (BPT) will be carried out, based on RILEM RC 05 (RILEM, 1982) document that originally provides the procedure for steel bars reinforcement. Figure 1 illustrates the test configuration:

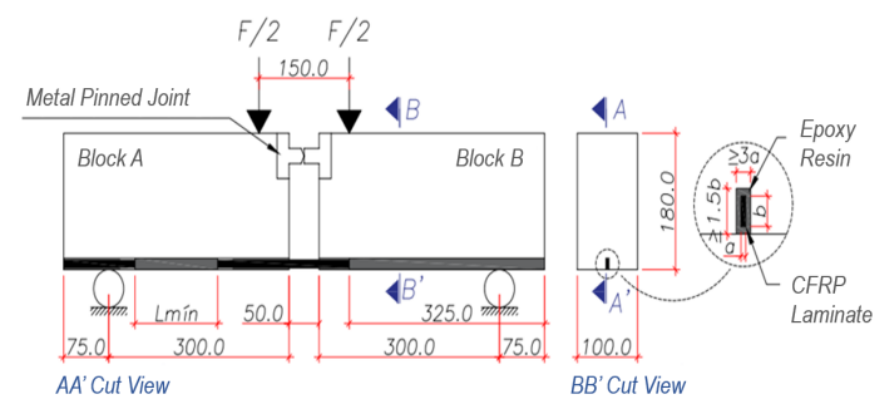

Image 1. Beam Pullout Test scheme with dimensions in millimeters.

This test configuration was proponed by Sena-Cruz e Barros (2004) and consists of two concrete blocks connected by a metallic pinned joint on the upper surface and by the CFRP strip on the lower surface. The laminate is anchored on Block B with a $325 \mathrm{~mm}$ length, while on Block $A$ the anchorage length is variable. Three different anchorage lengths will be tested: $70 \mathrm{~mm}, 160 \mathrm{~mm}$ and $210 \mathrm{~mm}$, each length presenting two beams, totalizing six tests.

\section{Conclusions}

It is expected that the analysis of the tests results and the study of the specimens' failure mode will provide an experimental basis to evaluate the bond resistance of PRFC laminates applied using the NSM method for different anchorage lengths, characterizing the bonding behavior on the CFRP/epoxy and epoxy/concrete interfaces.

DE LORENZIS, L., e TENG, J. G. Near-surface mounted FRP reinforcement: An emerging technique for strengthening structures. Composites Part B Engineering, v. 38, n.2, p 119-143, March. 2007.

FONSECA, T. C. C. S. Reforço e incremento da rigidez à flexão de ligações vigapilar de estruturas de concreto pré-moldado com Polímero Reforçado Com Fibra De Carbono (PRFC). 2007. 203 p. Dissertação (Mestrado) - Escola de Engenharia de São Carlos, Universidade de São Paulo, São Carlos

RILEM. RC 5: Bond test for reinforcement steel. 1. Beam test. RILEM Recommendations for the Testing and Use of Constructions Materials. 1982. p. 213 - 7

SENA-CRUZ, J. \& BARROS, J. A. O. Bond between Near-Surface Mounted CarbonFiber-Reinforced Polymer Laminate Strips and Concrete. Journal of Composite for Construction, 8(6), p. 517-527, November. 2004.

SENA-CRUZ, J. et al., NSM Systems. In_. Design Procedures for the Use of Composites in Strengthening of Reinforced Concrete Structures. First ed. Dordrecht: Springer Netherlands, 2016. Cap 8, p. $303-389$ 